\title{
Study on Leaching and Biosorption Processes of Some Economic Metals using Escherichia coli from Laterite Ore, Sinia, Egypt
}

\author{
Shimaa S Hussien ${ }^{1 *}$, Osman A Desouky ${ }^{2}$ and Said E Mohamady ${ }^{3}$ \\ ${ }^{1}$ Assistant Professor of Microbiology, Ore Processing Department, Nuclear Materials Authority, Cairo, Egypt \\ ${ }^{2}$ Assistant Professor of Inorganic Chemistry, Ore Processing Department, Nuclear Materials Authority, Cairo, Egypt \\ ${ }^{3}$ Lecturer of Inorganic Chemistry, Ore Processing Department, Nuclear Materials Authority, Cairo, Egypt
}

\begin{abstract}
The potentiality of Escherichia coli dead biomass for biosorption of rare earth elements (REEs) and uranium (VI) from chloride leach liquor of laterite ore was evaluated. The effects of different acid, different concentration of hydrochloric acid, contact time, solid/liquid phase ratio and temperature on leaching efficiency of laterite ore were investigated. The optimum leaching conditions were $2 \mathrm{M}$ acid with a Solid/Liquid ratio of $1 / 20$ at $90^{\circ} \mathrm{C}$ for $4 \mathrm{~h}$ and using an ore grain size of -60 mesh. The maximum recovery of REEs $70 \%$ and uranium $85 \%$ from chloride leach liquor of laterite ore using $E$. coli biomass was studied. The optimum biosorption conditions were as follows: $60 \mathrm{~min}$ as contact time, $4 \mathrm{~g} / 100 \mathrm{~mL}$ as the biosorbent dosage, $50^{\circ} \mathrm{C}$ as temperature and $175 \mathrm{rpm}$ as agitation speed using alkaline pretreated $E$. coli with $0.2 \mathrm{~N}$ $\mathrm{NaOH}$. The biosorption mechanism was explored by characterization of the biosorbent before and after biosorption using scanning electron microscopy (SEM) and Fourier transform infrared spectroscopy (FTIR) revealed that $E$. coli was a good choice as biosorbent agent for REEs and uranium ions removal from aqueous solution.
\end{abstract}

\section{Keywords}

Hydrochloric acid, Laterite ore, Escherichia coli, Biosorption, Economic metals

\section{Introduction}

Laterite ore was found in southwestern Sinai, Egypt. It has been found to host several economic metal values. These include $\mathrm{Al}, \mathrm{Si}, \mathrm{Mg}, \mathrm{Ca}, \mathrm{Ni}, \mathrm{P}, \mathrm{REEs}$ and $\mathrm{U}$ beside several $\mathrm{Mn}$ minerals. Several leaching studies have been performed upon comparable Abu Zeneima ore from different locations, but with different constituents and grades of the economic metal values as $U$ and other valuable elements [1,2]. They concluded that both metal values could be almost completely leached by mineral acid under mild agitation or percolation leaching conditions. Lanthanides and uranium are strategic elements and essential for many applications. One of such application is as catalyst for petroleum cracking, phosphors in color television sets, as polishing powder, in flint stones, ignition device, super conductor, hydrogen storage, secondary battery, in optical lenses, in streetlights, searchlights. While, uranium as a fuel in nuclear power plants and nuclear weapons [3].

There are many methods such as chemical precipitation, ion exchange, solvent extraction and sorption for removing rare earth elements from solution [4]. These traditional methods have some disadvantages, such as high consumption of reagent and energy, low selectivity, high operational cost and generation of secondary pollutants [5].
Biosorption has been portrayed an emerging and potential technology which involved the sorption of dissolved metals from bearing solution by a biomaterials. Several biomaterials including bacteria, fungi, algae and agriculture wastes were identified as potential candidates for the biosorption of the desired metals [6]. The metal biosorption process is a two-step process. In the first step, metal ions are adsorbed on the surface of cells by interactions between metals and functional groups displayed on the surfaces of cells. This step called passive biosorption, is metabolism independent and proceeds rapidly by any one or a combination of the following metal binding mechanisms: coordination, ion exchange, physical biosorption or inorganic micro precipitation. Passive biosorption is a dynamic equilibrium of reversible

*Corresponding author: Shimaa S Hussien, Assistant Professor of Microbiology, Ore Processing Department, Nuclear Materials Authority, P.O. Box 530 El-Maadi, Cairo, Egypt

Accepted: May 04, 2019

Published online: May 06, 2019

Citation: Hussien SS, Desouky OA, Mohamady SE (2019) Study on Leaching and Biosorption Processes of Some Economic Metals using Escherichia coli from Laterite Ore, Sinia, Egypt. Adv Environ Stud 3(1):179-190 
Citation: Hussien SS, Desouky OA, Mohamady SE (2019) Study on Leaching and Biosorption Processes of Some Economic Metals using Escherichia coli from Laterite Ore, Sinia, Egypt. Adv Environ Stud 3(1):179-190

biosorption-desorption. In the second step, due to active metal ions penetrate the cell membrane and enter into the cells. Metal Uptake by non-living cells is mainly passive mode [7]. The desorption process has the purpose of recovering the biosorbed metals while regenerating the biomass that could be used in subsequent sorption and desorption cycles [8] investigated that $B$. subtilis 168 exhibited a greater uranium retention capacity in comparison to those from $P$. putida 3301. In addition to, [9] mentioned the ability of $B$. subtilis alginate-chitosan microcapsule to remove uranium ion from aqueous solution. Moreover, the optimum values of $\mathrm{pH}$ was 6; immobilized spherule dosage was 3.5; temperature was 20 ${ }^{\circ} \mathrm{C}$; initial uranium ion concentration was $150 \mathrm{mg} / \mathrm{L}$; contact time was $3 \mathrm{~h}$ of uranium ion absorption. In this study, the use of $E$. coli as a biosorbent was tested for biosorption REEs and $\mathrm{U}$ ions from leach liquor of laterite ore. The effects of metal

Table 1: Chemical composition of the laterite ore sample.

\begin{tabular}{|l|l|l|l|}
\hline Constituent & $\mathbf{W t} . \%$ & Constituent & $\mathbf{W t} . \%$ \\
\hline $\mathbf{R E}_{\mathbf{2}} \mathbf{O}_{\mathbf{3}}$ & 1.92 & $\mathbf{K}_{\mathbf{2}} \mathbf{O}$ & 0.98 \\
\hline $\mathbf{F e}_{\mathbf{2}} \mathbf{O}_{\mathbf{3}}$ & 22.50 & $\mathbf{S i O}_{\mathbf{2}}$ & 21.90 \\
\hline $\mathbf{M n O}_{\mathbf{2}}$ & 12.60 & $\mathbf{A l}_{\mathbf{2}} \mathbf{O}_{\mathbf{3}}$ & 10.40 \\
\hline $\mathbf{C a O}$ & 4.20 & $\mathbf{P}_{\mathbf{2}} \mathbf{O}_{\mathbf{5}}$ & 2.80 \\
\hline $\mathbf{M g O}$ & 3.50 & $\mathbf{H}_{\mathbf{2}} \mathbf{O}^{-}$ & 3.30 \\
\hline $\mathbf{T h O}_{\mathbf{2}}$ & $20 \mathrm{ppm}$ & $\mathbf{H}_{\mathbf{2}} \mathbf{O}^{+}$ & 5.50 \\
\hline $\mathbf{U}_{\mathbf{3}} \mathbf{O}_{\mathbf{8}}$ & $230 \mathrm{ppm}$ & LOI & 7.40 \\
\hline $\mathbf{N a}_{\mathbf{2}} \mathbf{O}$ & 2.39 & Total & 99.80 \\
\hline
\end{tabular}

$\mathbf{R E}_{\mathbf{2}} \mathbf{O}_{\mathbf{3}}$ : Rare earth oxides. ion concentration, $\mathrm{pH}$, biosorbent dosage, contact time and temperature on the biosorption process were discussed.

\section{Materials and Methods}

\section{Ore composition}

Laterite ore was found in southwestern Sinai, predominantly on the three members of Um-bogma formation and to lesser extent in the base of El-Hashash formation through the Nuclear Materials Authority, (NMA) of Egypt. The chemical analysis of the studied laterite ore material is given in Table 1 for the major oxides. Scanning electron microscope was used for characterization of laterite ore sample as shown in Figure 1.

\section{Preparation of laterite leach liquor}

Different leaching conditions were studied to attain the maximum possible leaching efficiency of the metal values. These conditions include different acid leaching agents, different concentration from the used acid, contact time, solid/liquid phase ratio and temperature. The leaching efficiency of the metals was calculated from the analysis of the pregnant leach solution after filtering and washing the slurry.

\section{Microorganism and biosorbent preparation}

Escherichia coli isolated from laterite ore on nutrient agar medium. The obtained bacterial isolate cultured on EC medium. The medium composition is as follows $(\mathrm{g} / \mathrm{L})$ : Tryptose 20; Lactose 5; Bile salt mixture 1.5; $\mathrm{K}_{2} \mathrm{HPO}_{4} 4 ; \mathrm{KH}_{2} \mathrm{PO}_{4} 1.5 ; \mathrm{NaCl}$ 5 and $\mathrm{pH} 6.9$ [10]. E. coli culture was incubated at $37^{\circ} \mathrm{C}$ for 1-3 days on EC medium and biomass obtained was taken and

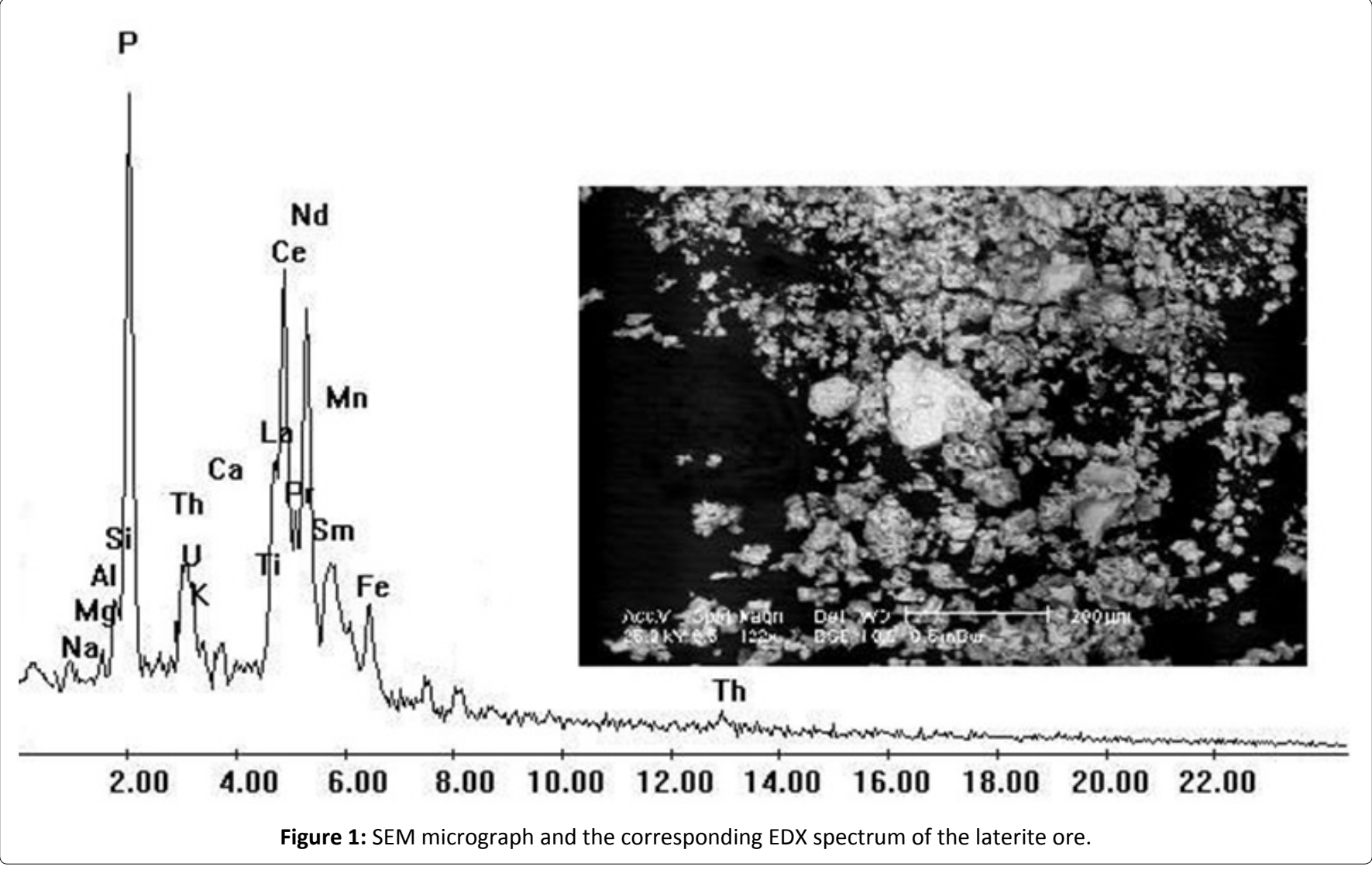


dried at $80{ }^{\circ} \mathrm{C}$ for about $3 \mathrm{hrs}$. Dried bacterial biomass was powdered and used for further studies.

\section{Biosorption experiments}

The biosorption experiments were conducted with 100 $\mathrm{mL}$ the chloride pregnant leach solution with adsorbent dosage was $1 \mathrm{~g}$ in $250 \mathrm{~mL}$ Erlenmeyer flask at $\mathrm{pH} 2.0$ for 60 min contact time at room temperature $30 \pm 1^{\circ} \mathrm{C}$. The effect of contact time was carried out for different contact times $(15,30,45,60,120,180$ and $240 \mathrm{~min})$. The effect of biomass loading studies was carried with different biosorbent dosages $(1,2,3,4$ and $5 \mathrm{~g})$. The effect of temperature was achieved by different temperature $\left(20,30,40,50\right.$ and $\left.60^{\circ} \mathrm{C}\right)$. The effect of agitation speed was studies using different agitation speed (50, 100, 150, 200 and $250 \mathrm{rpm})$. Finally, bacterial biomass was modified by various pretreatment like acid treatment, alkali treatment, sterilization and heat. All tested experiments were repeated three times.

\section{Analytical procedure}

Measurement of metal ions: The samples were taken at regular intervals, analyzed for $U$ \& REEs spectrophotometrically using the colorimetric determination (Metertech Inc, model SP-8001, UV-Visible) spectrometer, in all measurements, two ng are matched $5 \mathrm{~cm}^{3}$ quartz cells with a path length of $1 \mathrm{~cm}$ were used for sample and blank measurements usinazo III and I. All measurements were carried out at laboratory temperature [11].

SEM observation (SEM): The change in the surface morphology of pore structure and loaded biomass of $E$. coli were observed under high resolution Scanning electron microscope (ESEM), Philips XL30 vacuum at $30 \mathrm{KV}$.
Fourier transform infrared spectroscopy (FTIR): Fourier transform Infrared spectrophotometer was used to determine the functional groups presented on the surface of $E$. coli biomass before and after loading with $\mathrm{U}(\mathrm{VI})$ \& REEs Analytical Center, Cairo University, Egypt. The samples were prepared as $\mathrm{KBr}$ discs.

Binocular stereo microscope (BSM): Binocular stereo microscope equipped with digital camera (Model Meiji EMZ-TR-Japanas used to examine the crystals structure and photographing it. The apparatus was presented in (NMA), Cairo, Egypt.

\section{Desorption study}

Desorption experiments were performed by mixing $E$. coli loaded biomass (500 mg dry weight) with desorbing agents $50 \mathrm{~mL}$ of $\left(0.5 \mathrm{~N} \mathrm{HCl}, 0.5 \mathrm{~N} \mathrm{NaOH} 0.5 \mathrm{~N} \mathrm{H}_{2} \mathrm{SO}_{4}\right.$ and $0.1 \mathrm{~N}$ EDTA) for $1 \mathrm{~h}$ on a rotary shaker (175 rpm) at $30^{\circ} \mathrm{C}$ for three cycles to study the elution rate. The U(VI) \& REEs yields were precipitated from the desorbent solutions by different precipitating agent where, excess of $\mathrm{NaOH} 20 \%$ or ammonium hydroxide $33 \%$ or oxalic acid $10 \%$ was added. Then the suspensions left overnight for crystallization [12].

The obtained crystals of ammonium diuranate and rare earths oxalate were characterized using Binocular stereomicroscope apparatus (BSM) to study the structure form and photographed it.

\section{Statistical analysis}

All obtained experimental results were subjected to statistical analysis using statistical software SPSS (Ver, 10) as described by [13].

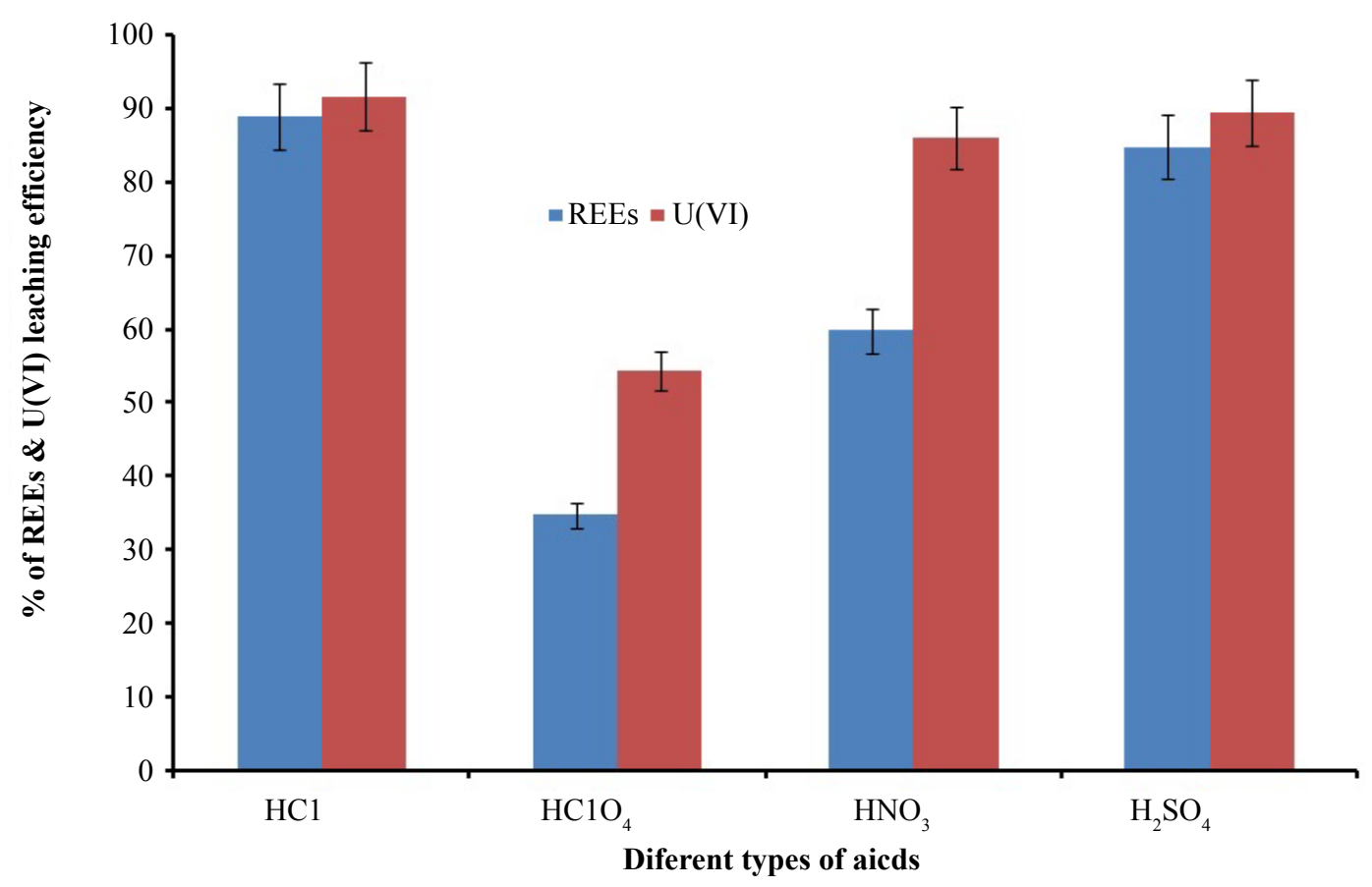

Figure 2: Effect of different acids on REEs \& $\mathrm{U}(\mathrm{VI})$ ion leaching efficiency. 


\section{Results and Discussion}

\section{Factors affecting the dissolution of valuable ele- ments from laterite ore}

Effect of different acid on REEs and uranium dissolution: The influence of different kind of acid has significant effect on REEs and $\mathrm{U}(\mathrm{VI})$ was carried out using $\mathrm{H}_{2} \mathrm{SO}_{4}, \mathrm{HNO}_{3}, \mathrm{HCl}$ and $\mathrm{HClO}_{4}$. The $\mathrm{S} / \mathrm{L}$ ratio was maintained at $1: 5$, the contact time $2 \mathrm{hrs}$, at $50{ }^{\circ} \mathrm{C}$ and the concentration of acids are $2 \mathrm{M}$. The results are shown in Figure 2. It was appeared that $\mathrm{HCl}$ was the best acid gives the highest leaching efficiency for REEs and $\mathrm{U}(\mathrm{VI})$ ions. The type of anion and his geometry with influence the decrease in the REEs and $\mathrm{U}(\mathrm{VI})$ ions leaching efficiency in the presence of sulphate and nitrate compared to chlorine anion.
Effect of different concentration of $\mathrm{HCl}$ on REEs and $\mathrm{U}(\mathrm{VI})$ dissolution: From the previous factor found that $\mathrm{HCl}$ is the most suitable acid for leaching of both REEs and uranium, different concentrations of $\mathrm{HCl}$ and their effect on the leaching process were studied. In different beakers, we carried out the experiments having concentration ranging from $1-8 \mathrm{M}$ was added to samples at constant temperature $50{ }^{\circ} \mathrm{C}, \mathrm{S} / \mathrm{L}$ phase ratio of $1: 5$ and contact time of $2 \mathrm{~h}$. The results are appeared in Figure 3. It was observed that the concentration of REEs and $\mathrm{U}(\mathrm{VI})$ dissolution was increased gradually from $1 \mathrm{M}$ to $2 \mathrm{M}$ and decreased after that. So that $2 \mathrm{M} \mathrm{HCl}$ was the best concentration used in leaching of REEs and $\mathrm{U}(\mathrm{VI})$. The decrease of leaching by increasing $\mathrm{HCl}$ concentration After $2 \mathrm{M}$ may be due to the formation of unreachable complex special. Or may be attributed to, the readsorption process of $\mathrm{U}(\mathrm{VI})$ and REEs on the surface of the solid residue.

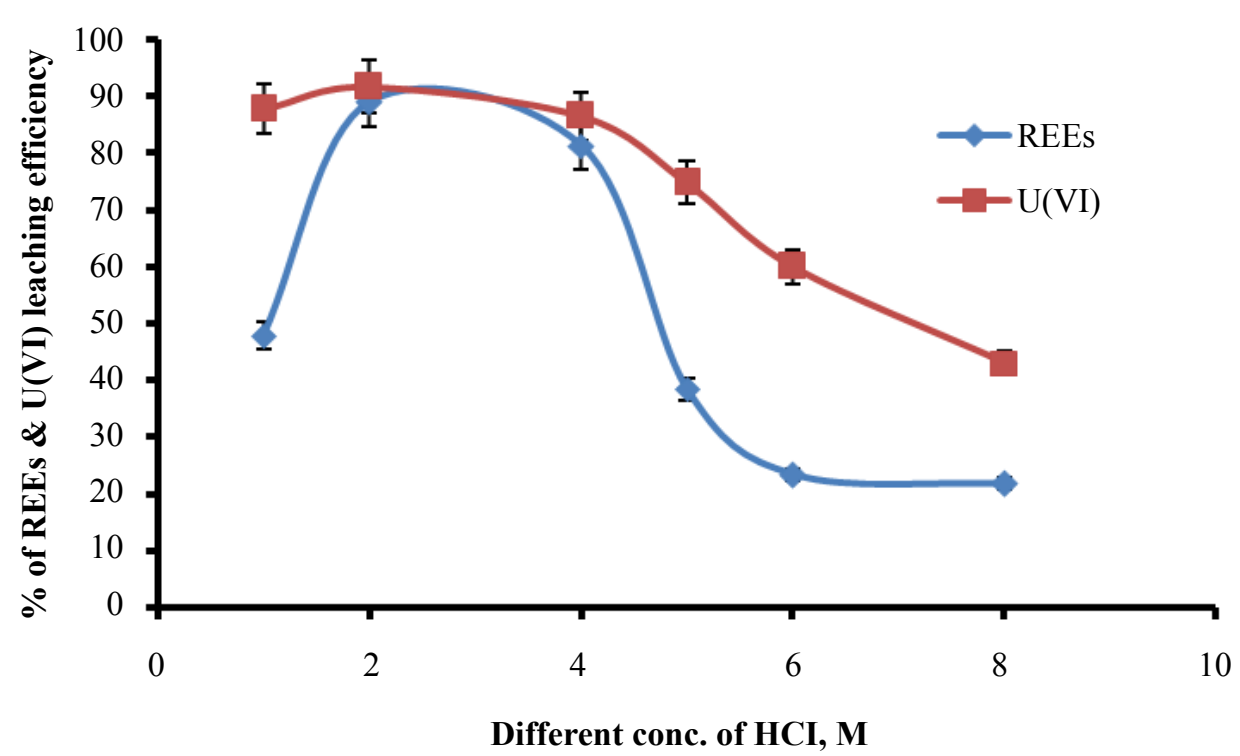

Figure 3: Effect of different $\mathrm{HCl}$ concentration on REEs \& $\mathrm{U}(\mathrm{VI})$ leaching efficiency.

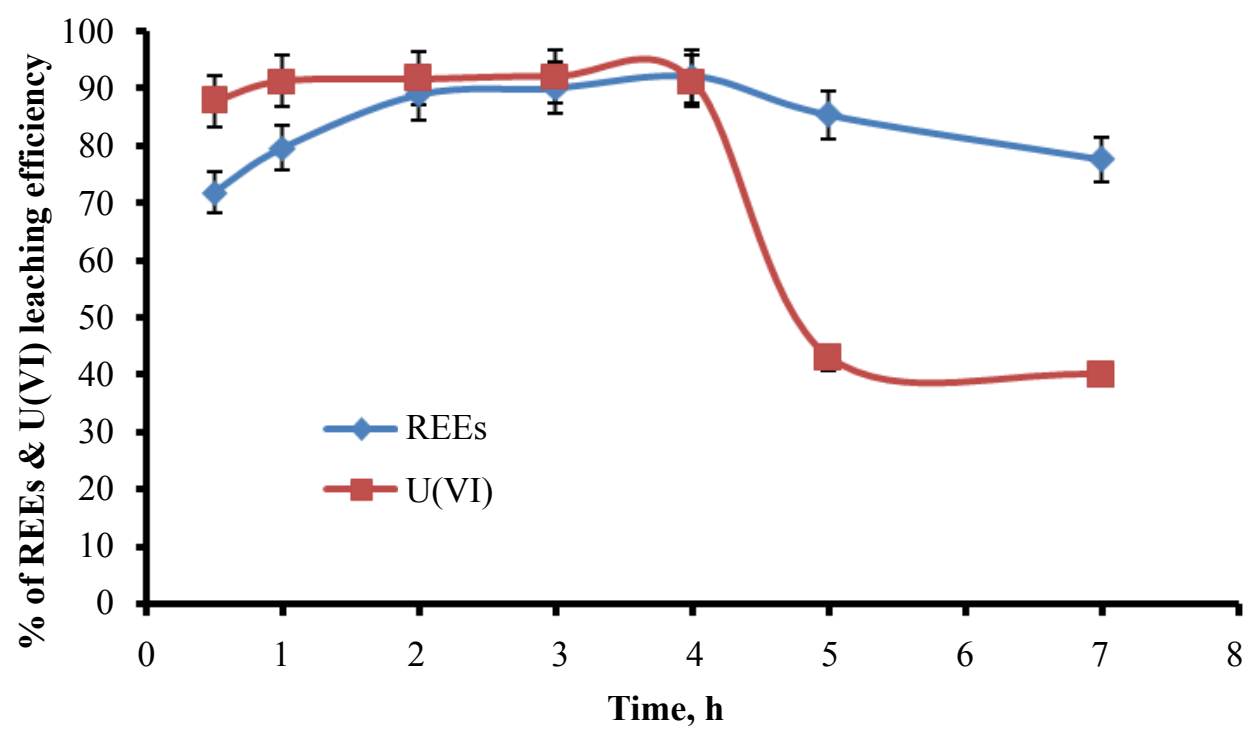

Figure 4: Effect of different contact time on REEs \& U(VI) leaching efficiency. 
Effect of contact time: The concentrations of REEs and $\mathrm{U}(\mathrm{VI})$ were studied, in which the leaching of these elements using $2 \mathrm{M} \mathrm{HCl}$ was investigated at equilibration time ranging from 0.5-7 $\mathrm{h}$. The other different factors were kept constant at $2 \mathrm{M} \mathrm{HCl}, \mathrm{S} / \mathrm{L}$ phase ratio of $1: 5$ at temperature of $50{ }^{\circ} \mathrm{C}$. The obtained results were illustrated in Figure 4 REEs and $\mathrm{U}(\mathrm{VI})$ respectively. It was observed that the concentration of REEs was gradually increased from $0.5 \mathrm{~h}$ to $4 \mathrm{~h}$, and then it was decreased above this time, but in case of $U(V I)$, it was observed that the concentration was gradually increased from $0.5 \mathrm{~h}$ to $2 \mathrm{~h}$, and then it was decreased above this time. Excess time may be encouraging the readsorpion process which decreases the leaching process.

Effect of solid/liquid phase ratio: In this experiment the solid/liquid phase ratio for the leaching of REEs and $U(V I)$ was investigated with different ratios between (1:5 to 1:40) with fixing the other factors affecting the leaching efficiency such as $2 \mathrm{M} \mathrm{HCl}, 4 \mathrm{~h}$ of equilibration time at temperature of $50{ }^{\circ} \mathrm{C}$. The results were shown in Figure 5 for the leaching of REEs and $\mathrm{U}(\mathrm{VI})$ respectively. From the obtained results, it was noticed that, the concentration of REEs and $\mathrm{U}(\mathrm{VI})$ was increased gradually from (1:5 to 1:20) and decreased from (1:20 to $1: 40)$ and it was clear that $1: 20$ solid/liquid phase ratio was the best and suitable for dissolution of elements from these sample. S/L ratio 1:20 gives the highest leaching efficiency, after this ratio large volume was not recommended due to the analysis and biosorption process.

Effect of temperature: The experiment was studied for the effect of temperature ranging from $\left(50-100{ }^{\circ} \mathrm{C}\right)$ on the leaching of REEs and $\mathrm{U}(\mathrm{VI})$ from sample. All other parameters of $2 \mathrm{M} \mathrm{HCl}$, solid/ liquid phase ratio of $1: 20$ in addition to 4 $\mathrm{h}$ of equilibration time were constant. The obtained results were illustrated in Figure 6 for the leaching of REEs and $\mathrm{U}(\mathrm{VI})$ respectively. From these results, it was noticed that the concentration of REEs and $\mathrm{U}(\mathrm{VI})$ were increased gradually with increasing temperature, from $\left(50{ }^{\circ} \mathrm{C}\right.$ to $\left.90{ }^{\circ} \mathrm{C}\right)$ for both REEs and uranium. The increase of leaching efficiency after $90{ }^{\circ} \mathrm{C}$ was very slightly and for economic reason we chose

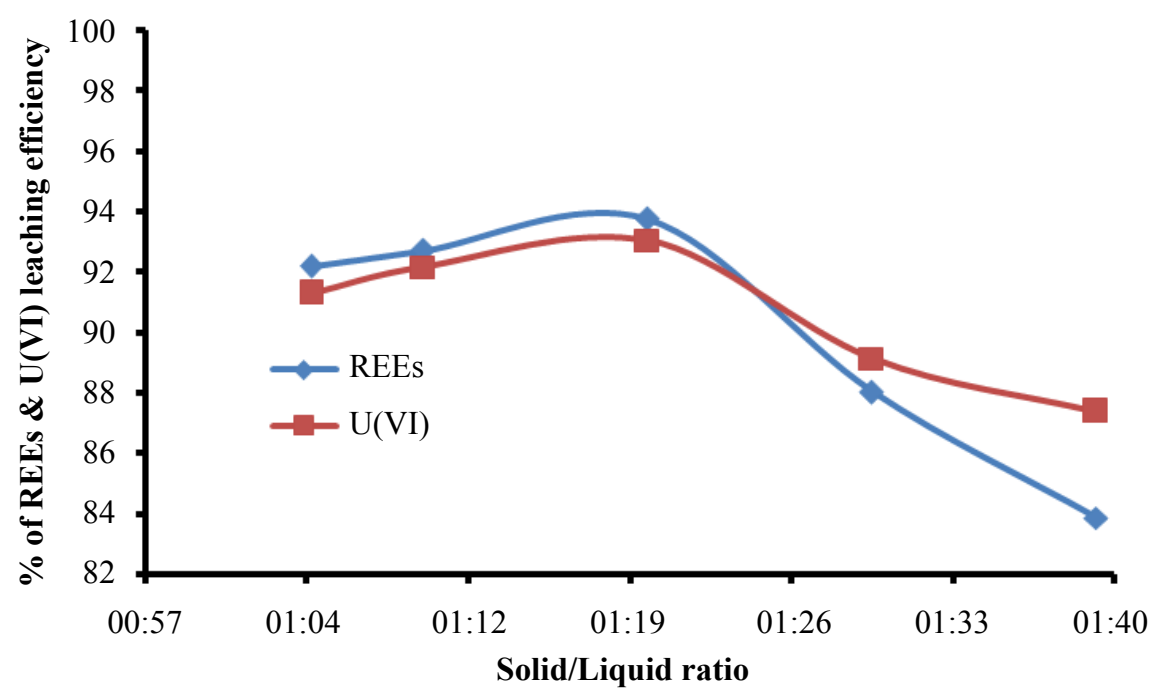

Figure 5: Effect of solid/liquid phase ratio on REEs \& U(VI) leaching efficiency.

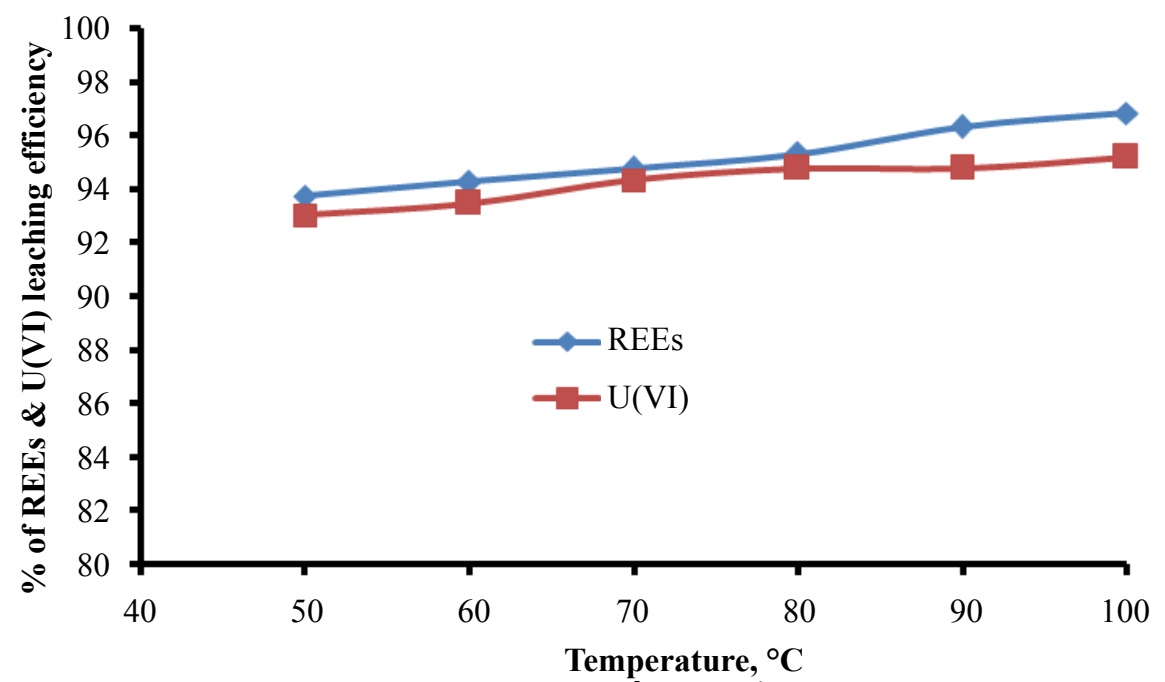

Figure 6: Effect of different temperature on $\operatorname{REEs}(\mathrm{K})$ \& $U(\mathrm{VI})(\mathrm{L})$ leaching. 
this temperature for optimal condition. From $50{ }^{\circ} \mathrm{C}$ to $90^{\circ} \mathrm{C}$ gradually leaching increases by increasing the temperature this may be attributed to increase random motion of the $\mathrm{Cl}^{-}$anions and the metal in the tested sample, increase the formation metal extractable which increasing the leachability.

The chemical composition of the obtained pregnant chloride leach liquor was illustrated in Table 2.

\section{Effect of different factors influence the biosorption of $\mathrm{U}(\mathrm{VI})$ and REEs from pregnant chloride leach liquor of laterite ore using $E$. coli biomass}

Effect of contact time: Effect of contact time using dead biomass of $E$. coli was studied and result was shown in Figure 7. Initially there was a rapid increase in the adsorption and as the time increases it reaches equilibrium and remains constant after the equilibrium time. The percentage removal was around $75 \%$ and $57 \%$ for $\mathrm{U}(\mathrm{VI})$ and REEs, respectively with equilibrium time of $60 \mathrm{~min}$. This indicated that, as the contact time increased, more and more functional groups participated in biosorption of metal ions until it reaches equilibrium then active sites on the biosorbent were filled. The rate of biosorption became gradually constant and reached a plateau [14]. As time passes the metal uptake by the sorbent surface slows down as the competition for the

Table 2: Chemical composition of leaching solution after applying the optimum conditions for leaching REEs and U(VI).

\begin{tabular}{|l|l|l|l|}
\hline Elements & Conc.,\% & Elements & Conc.,\% \\
\hline $\mathrm{RE}_{2} \mathrm{O}_{3}$ & 1.85 & $\mathrm{U}_{3} \mathrm{O}_{8}$ & $218 \mathrm{ppm}$ \\
\hline $\mathrm{Fe}_{2} \mathrm{O}_{3}$ & 12.58 & $\mathrm{Na}_{2} \mathrm{O}_{3}$ & 1.85 \\
\hline $\mathrm{MnO}_{2}$ & 4.30 & $\mathrm{~K}_{2} \mathrm{O}$ & 0.79 \\
\hline $\mathrm{CaO}$ & 2.77 & $\mathrm{SiO}_{2}$ & 14.88 \\
\hline $\mathrm{MgO}$ & 2.20 & $\mathrm{Al}_{2} \mathrm{O}_{3}$ & 5.64 \\
\hline $\mathrm{P}_{2} \mathrm{O}_{5}$ & 1.55 & & \\
\hline
\end{tabular}

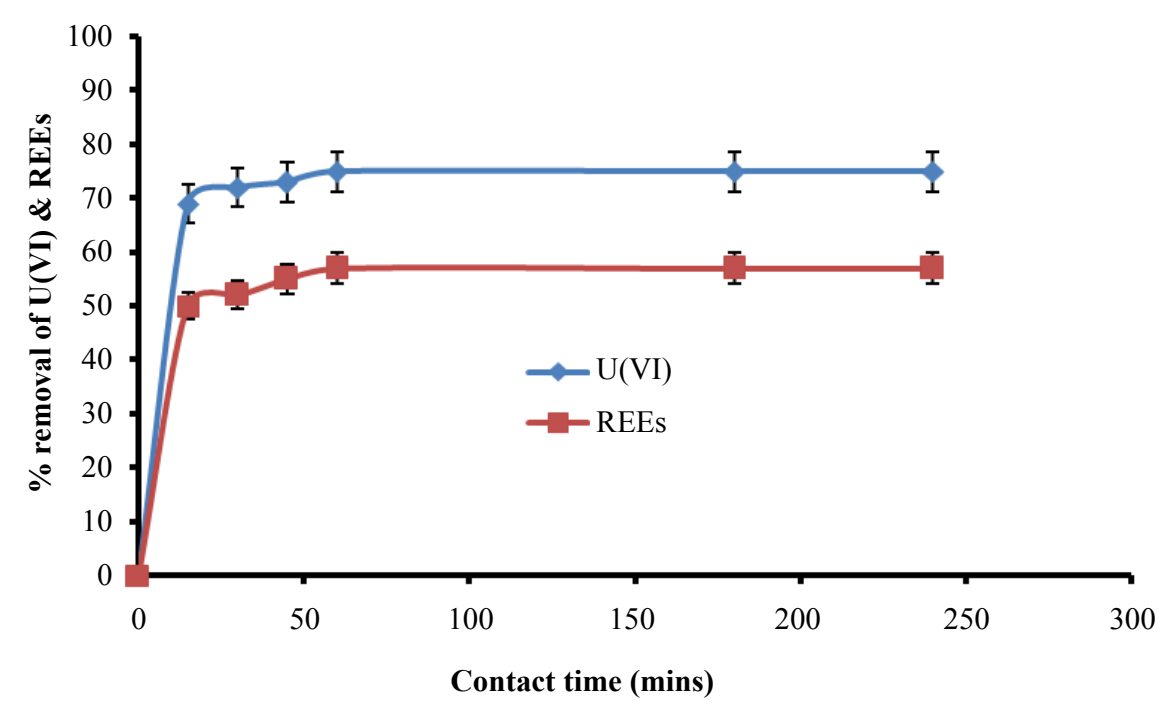

Figure 7: Effect of contact time on the biosorption of $\mathrm{U}(\mathrm{VI})$ \& REEs ions by E. coli biomass.

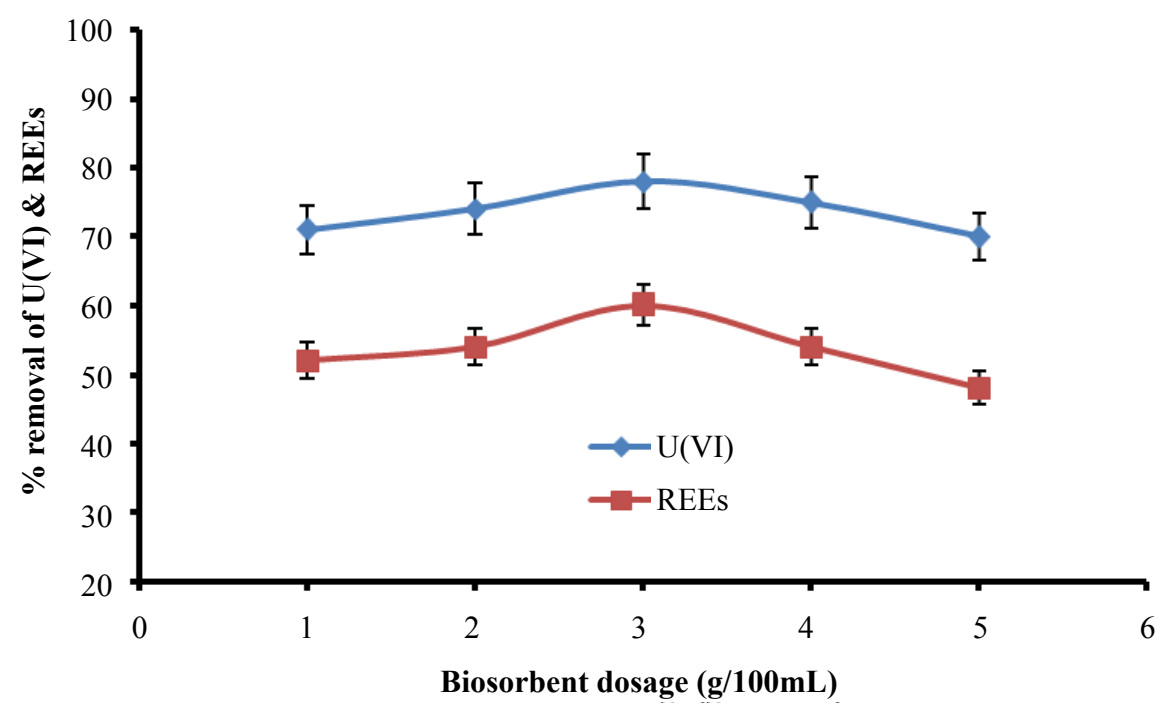

Figure 8: Effect of biosorbent dosage on the biosorption of $\mathrm{U}(\mathrm{VI})$ \& REEs ions by $E$. coli biomass. 
decreasing availability of active sites intensifies by the metal ions remaining in the solution [15].

Effect of biosorbent dosage: Biosorbent dose also is an important parameter, which can influence the biosorption capacity and efficiency. The effect of adsorbent dosage on $\mathrm{U}(\mathrm{VI})$ \& REEs ions removal is shown in Figure 8. The percentage removal was around $78 \%$ and $60 \%$ for $\mathrm{U}(\mathrm{VI})$ and REEs ions, respectively with biomass dose $3 \mathrm{~g}$. When biomass dose increases from $1.0 \mathrm{~g}$ to $3.0 \mathrm{~g}, \mathrm{U}(\mathrm{VI})$ \& REEs ions sorption efficiency increases significantly, this mainly due to the increase of active sites in biomass, so the metal ions can easily go onto the adsorption sits. When the adsorbent dosage exceeds $3.0 \mathrm{~g}$, the percentage removal of $\mathrm{U}(\mathrm{VI})$ \& REEs ions decreases, and it cane be explained that high dosage material produces a 'screen effect' on the cell wall, which protects the binding site [16].

Effect of temperature: The experiments were carried out at $20,30,40,50$ and $60^{\circ} \mathrm{C}$. The other parameters were kept constant. It was found that the temperature $50{ }^{\circ} \mathrm{C}$ was considered the suitable degree for maximum biosorption rate
$81 \%$ and $62 \%$ for $\mathrm{U}(\mathrm{VI})$ and REEs, respectively as appeared in Figure 9. Similar observation obtained by [17] they reported that the increase in biosorption with temperature may be attributed to either an increase in the number of active surface sites available for biosorption on the biosorbent due to the possible denaturation of the intact nature of the biosorbent agent or the decrease in the thickness of the boundary layer surrounding the biosorbent with temperature.

Effect of agitation speed: The effect of agitation speed on biosorption efficiency of $\mathrm{U}(\mathrm{VI})$ \& REEs ions was studied by varying the speed of agitation from 50 to $250 \mathrm{rpm}$, while keeping the other factors constant. As observed from Figure 10 , the metal ions biosorption efficiency generally increased with increasing agitation speed. It was found that the agitation speed $150 \mathrm{rpm}$ was considered the suitable speed for maximum biosorption rate $80 \%$ and $67 \%$ for $\mathrm{U}(\mathrm{VI})$ and REEs, respectively. These results can be associated to the fact that the increase of the agitation speed, improves the diffusion of metal ions towards the surface of the adsorbents. This also indicates that a shaking rate about $150 \mathrm{rpm}$ is sufficient to ensure that all the surface binding sites are made

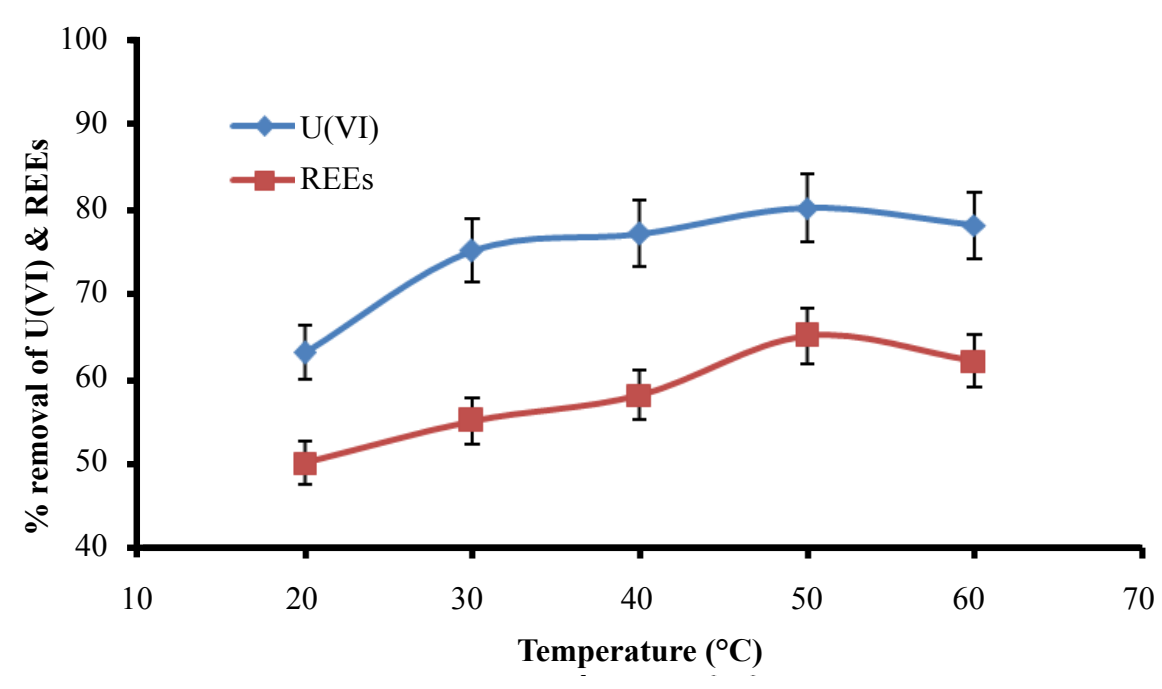

Figure 9: Effect of temperature on the biosorption of $\mathrm{U}(\mathrm{VI})$ \& REEs ions by E. coli biomass.

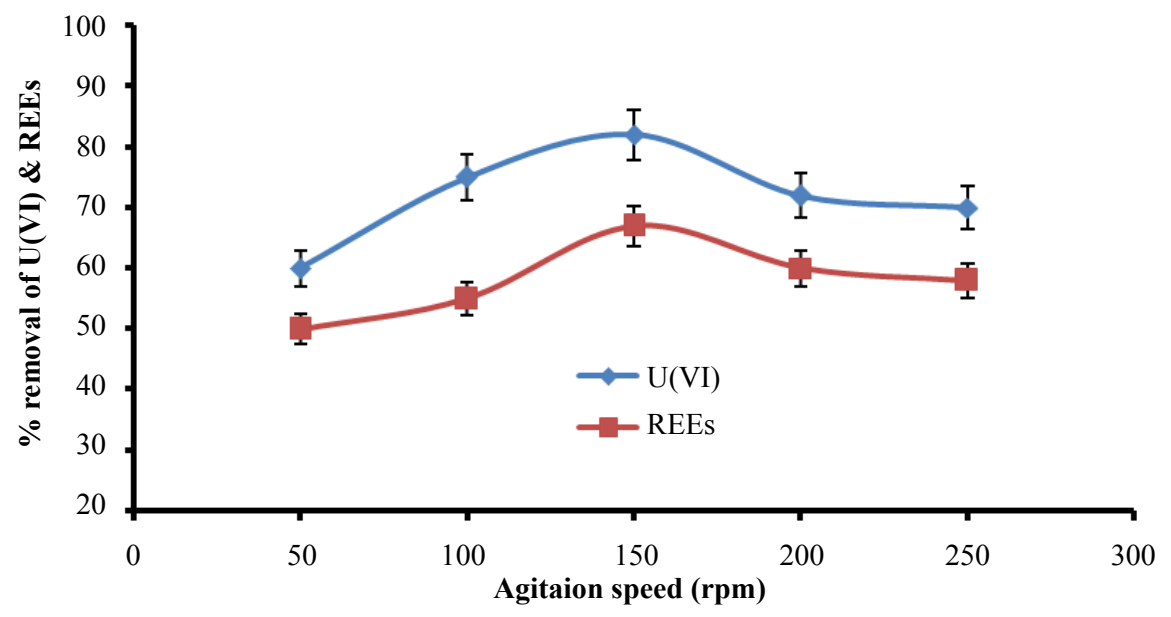

Figure 10: Effect of agitation speed on the biosorption of $U(V I) \&$ REEs ions by E. coli biomass. 


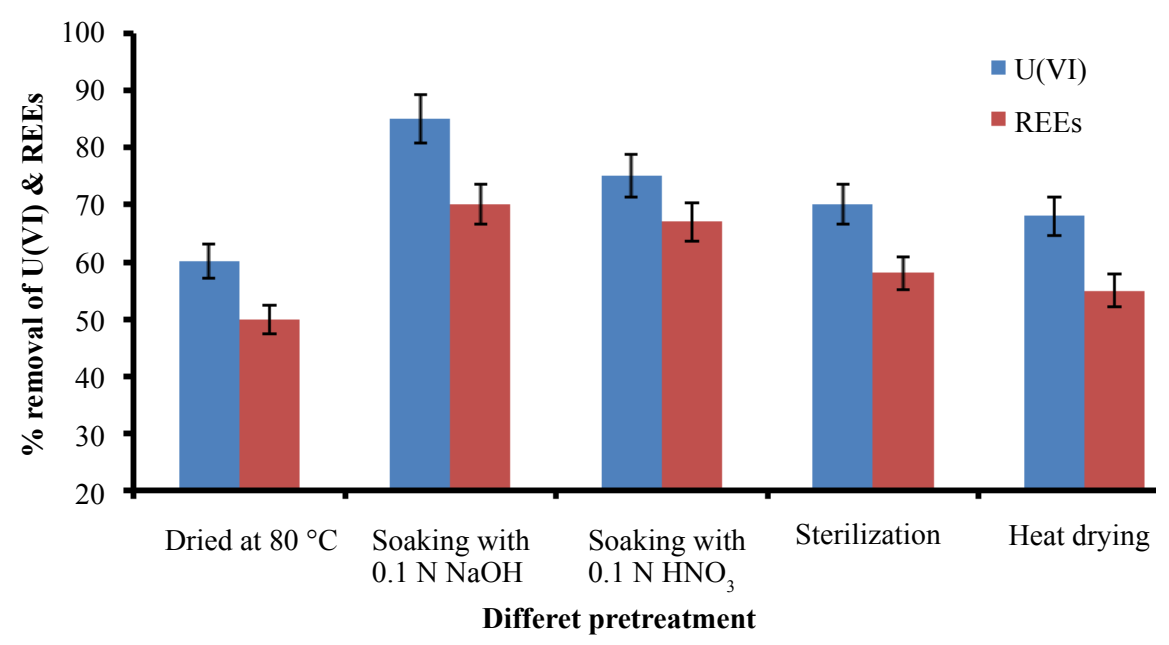

Figure 11: Effect of pretreatment of $E$. coli biomass on the biosorption of $\mathrm{U}(\mathrm{VI})$ \& REEs ions.

readily available for metal ions uptake [18].

Effect of pretreatment: Metal affinity to biomass can be manipulated by pre-treating the biomass with alkaline, acid, and heat which may increase the amount of metal sorbed [19]. The comparison for U(VI) \&REEs ions adsorption efficiency pretreated $E$. coli biomass was shown in Figure 11. It showed that the biomass pretreated with sodium VI) \& REEs hydroxide has better adsorption efficiency followed by acidity, sterilization and heat treatment. Adsorption of $U$ (ions varies because of the modifications in the cell wall. It was found that the biomass pretreated with sodium hydroxide was considered the suitable pretreatment which give maximum biosorption rate about $85 \%$ and $70 \%$ for $\mathrm{U}(\mathrm{VI})$ and REEs, respectively. The reason may be that alkali pretreatment was considered the best treatment could remove the amorphic polysaccharide on the cell wall and change the structure of the dextran and chitin, so the biomass could biosorbent much more metal ions on its surface. At the same time, $\mathrm{NaOH}$ could dissolve the inclusions in the cell which encumber biosorption, and expose much more active binding sites to improve the biosorption capacity. Furthermore $\mathrm{NaOH}$ makes proton to be dissociated from cell wall, resulting in the increase of negative functional groups, then the improvement of the biosorption capacity [20].

\section{Fourier transform infrared spectroscopy (FTIR)}

FITR was used to identify the biomass functional groups involved in the adsorbing process, which is important for elucidation of the surface-bonding mechanism. An infrared spectrum of the metal non-loaded biomass (control) was compared with loaded-REEs biomass. Infrared analysis elucidated the types of functional groups presents on the surface of biosorbent biomass. The IR spectra in the range of $\left(400-4000 \mathrm{~cm}^{-1}\right)$ revealed characteristic biosorption peaks assigned to native (control) and metal loaded for $E$. coli biomass was presented in Figure 12A and Figure 12B.

The FTIR spectrum of unloaded biosorbent showed several distinct and sharp adsorption bands of different wavelength. The FTIR spectra of loaded biomass indicated some shifts in some of characteristic bands. Change in the spectrum depicts change in functional groups of biomass after $\mathrm{U}(\mathrm{VI})$ \& REEs adsorption. This implied the possibility that biosorption could be taken place through ion exchange process or complexation. The FTIR spectrum showed that the peaks of hydroxyl and amine groups shifted from 3400.67 to 3426.64 $\mathrm{cm}^{-1}$, indicating the formation of more $-\mathrm{OH}$ and $-\mathrm{NH}$ by complexation; an anti-symmetric stretching peak of $-\mathrm{CH}$ shifting from 2927.38 to $2929.34 \mathrm{~cm}^{-1}$ by interaction with $\mathrm{U}(\mathrm{VI})$ \& REEs ions [21].

There is a high shift in the intensity of stretching peak of -OH from 2328.38 to $2365.26 \mathrm{~cm}^{-1}$ after uranium adsorption. This shift after uranium biosorption indicated the role of phosphate group in uranium biosorption. Involvement of phosphate group in intracellular metal uptake was also reported in the form of polyphosphate granules localized in or close to the vacuoles [22]. A symmetric stretching peak of $C$ $=\mathrm{O}$ shifting from $1,651.73$ to $1,651.73 \mathrm{~cm}^{-1}$. An enhancement of an amide II peak between 1533.92 to $1538.13 \mathrm{~cm}^{-1}$. The IR analysis of biosorbent specifically the $1650-1620 \mathrm{~cm}^{-1}$ band indicated the existence of the amide I band of amide bond in poly-N-acetyl glucosamine (chitin) and the protein peptide bond present in biomass considered to be due to combined effect of double bond stretching vibrations (mainly $C=O$ ) and hydrogen bonding [23]. The peak in the proximity shifted from 1447.31 to $1452.14 \mathrm{~cm}^{-1}$ responded to the symmetric vibrations of the $\mathrm{C}=\mathrm{C}$ at terminal amino acid on biomass [24]. A stretching vibration peak of C-N shifting from 1316.18 to $1350.17 \mathrm{~cm}^{-1}$. The amide linkages between amino acid and residues of proteins give arise to well known signatures in the infrared region of the electro-magnetic spectrum. Such mode arises from peptides/proteins bound to $U(V I)$ and REEs metal ions. A similar result was obtained by [25] they mentioned that Amide I and II stretching was found to be responsible for copper (II) and lead (II) bonding. A stretching vibration peak of C-O-C shifting from 1237.11 to $1233.25 \mathrm{~cm}^{-1}$ in $\mathrm{COOH}$ group, again strengthens the hypothesis that a carboxyl group was involved in metal biosorption [24]. A stretching peak of $\left(\mathrm{PO}_{4}^{-3}\right)$ orthophosphate group located at around 1074.16 to 1070.23 $\mathrm{cm}^{-1}$; and the reduced transmittance of and C-O-O peak at $953.35 \mathrm{~cm}^{-1}$ indicated that the presence of metals caused 


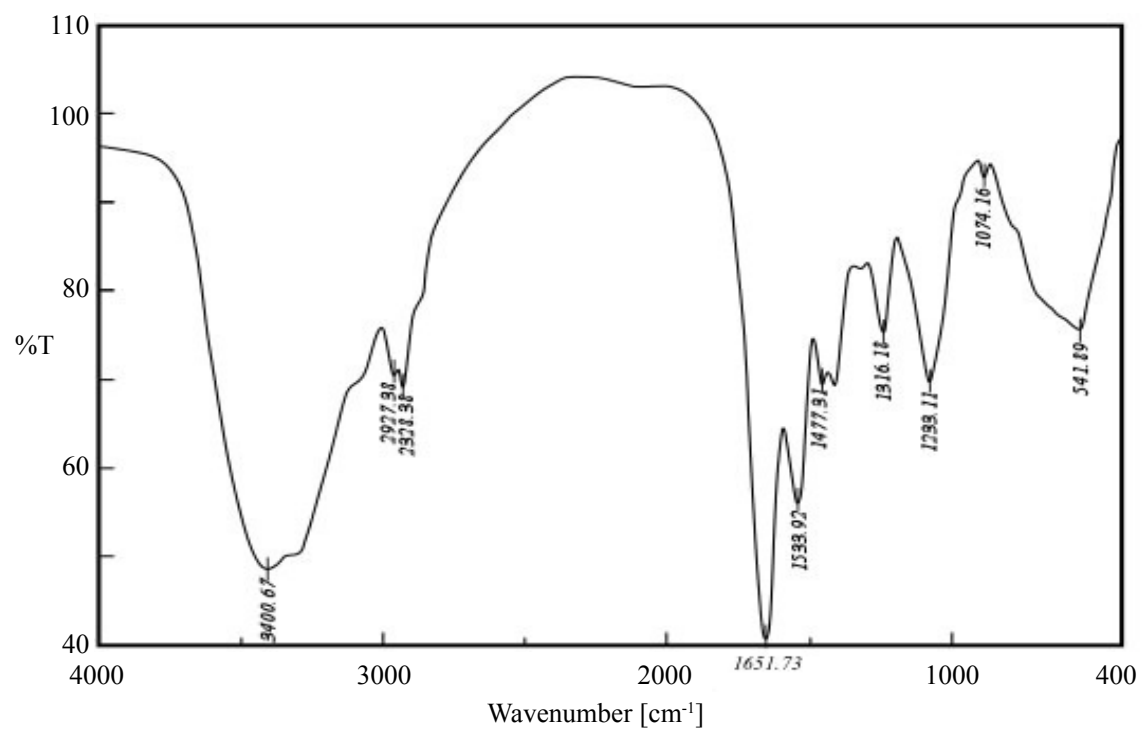

(A)

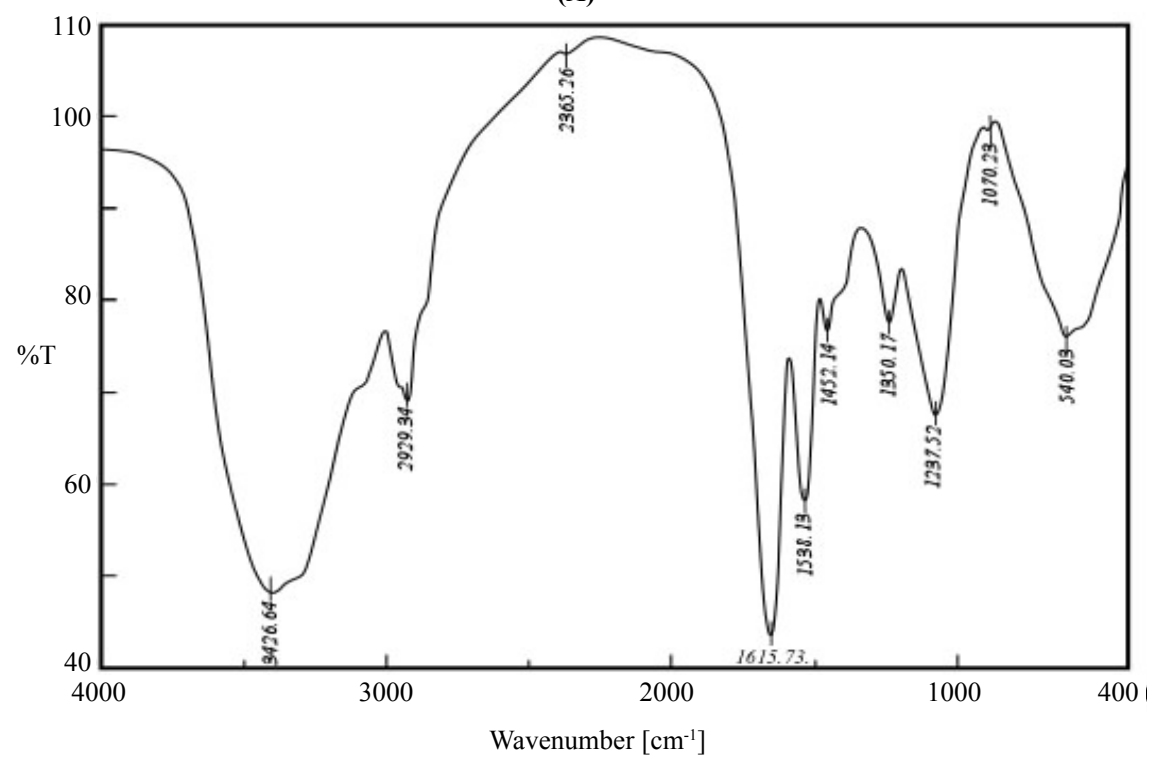

(B)

Figure 12: Infrared spectra of E. coli biomass non-loaded (control) (A) and loaded (B) with U(VI) \& REEs ions.

less stretching. Additionally, a report by [21] found that the presence of amino, carboxyl, hydroxyl, and carbonyl groups on the surface of Arthrobacter sp. 25 was responsible for the bonding of lead. These phenomena further supported the conclusion that available hydroxyl, amino, amide, carbonyl, and phosphate functional groups on the $E$. coli cell surface were associated with $U(\mathrm{VI})$ \& REEs biosorption.

\section{Scanning electron microscope (SEM)}

SEM images of $E$. coli with and without $\mathrm{U}(\mathrm{VI})$ \& REEs ions loading are shown in Figure 13A and Figure 13B. Metal ions loaded cells differed in morphology from the unloaded ones. For the samples containing the unloaded cells, the majority of cells remained intact, smooth, and closely connected with one another, providing a large surface area for biosorption Figure 13A. In the case of the loaded samples Figure 13B, the matrix layers of the cell wall appeared to shrink and stick. All microstructures porosities of $E$. coli appeared with bright appearance and seemed to be filled with $\mathrm{U}(\mathrm{VI})$ \& REEs ions. The changes in cellular morphology and size may result from mechanical force and reciprocation between surface-active components and metallic ions [26]. Therefore, this structural change was attributed to the strong cross linking of metal (U(VI) \& REEs) ions and negatively charged chemical groups on the cell wall polymers.

The EDX analysis showed that the elemental composition of $E$. coli biomass was significantly changed after U(VI) \& REEs ions biosorption Figure 14A and Figure 14B. Figure 14B shows signals of $U(\mathrm{VI}) \&$ REEs elements in the bacterial biomass. The adsorption of $\mathrm{U}(\mathrm{VI})$ \& REEs by E. coil occurred primarily on the cell surface.

\section{Desorption study}

Desorption/recovery of biosorbed metal is one of the most important aspects of any successful biosorption process development [27]. Figure 15 appeared the percentage of 

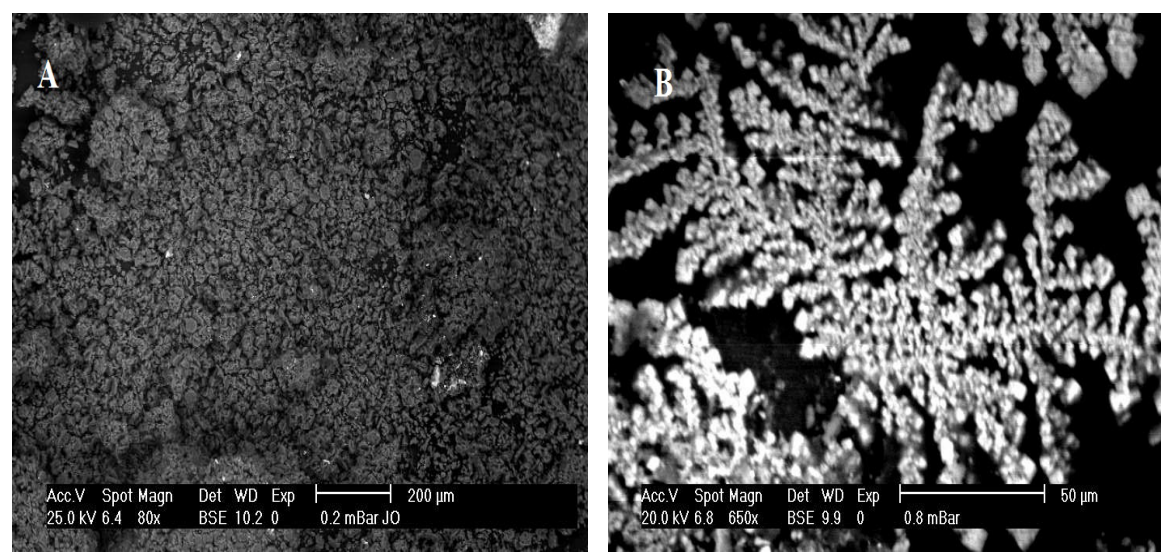

Figure 13: SEM images of $E$. coli biomass before (A) and after (B) U(VI) \& REEs ions uptake.

A

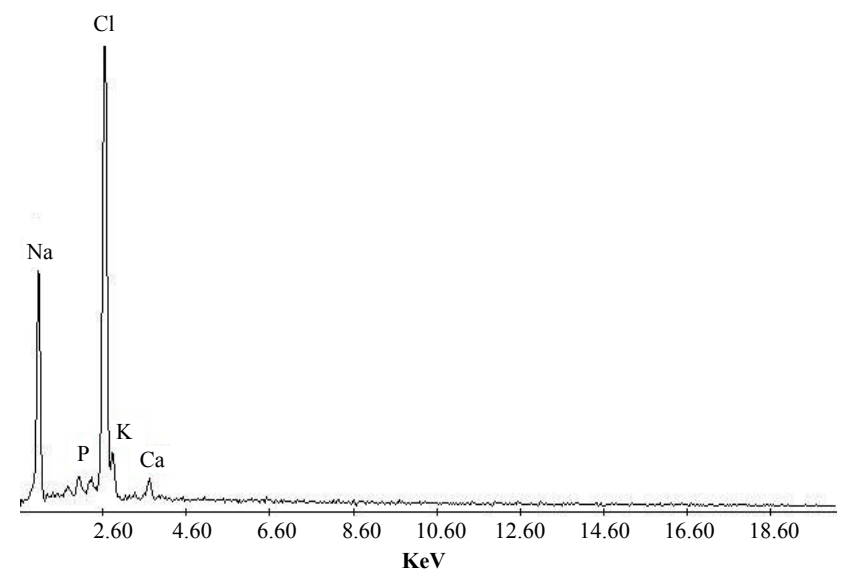

B

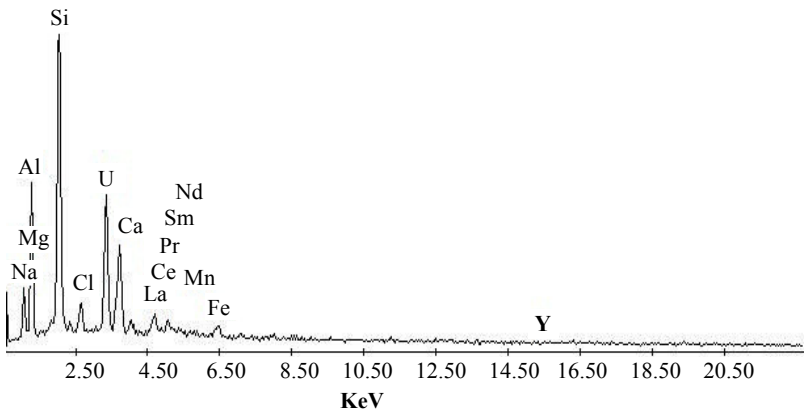

Figure 14: EDX spectra of $E$. coli biomass before (A) and after (B) U(VI) \& REEs ions uptake.

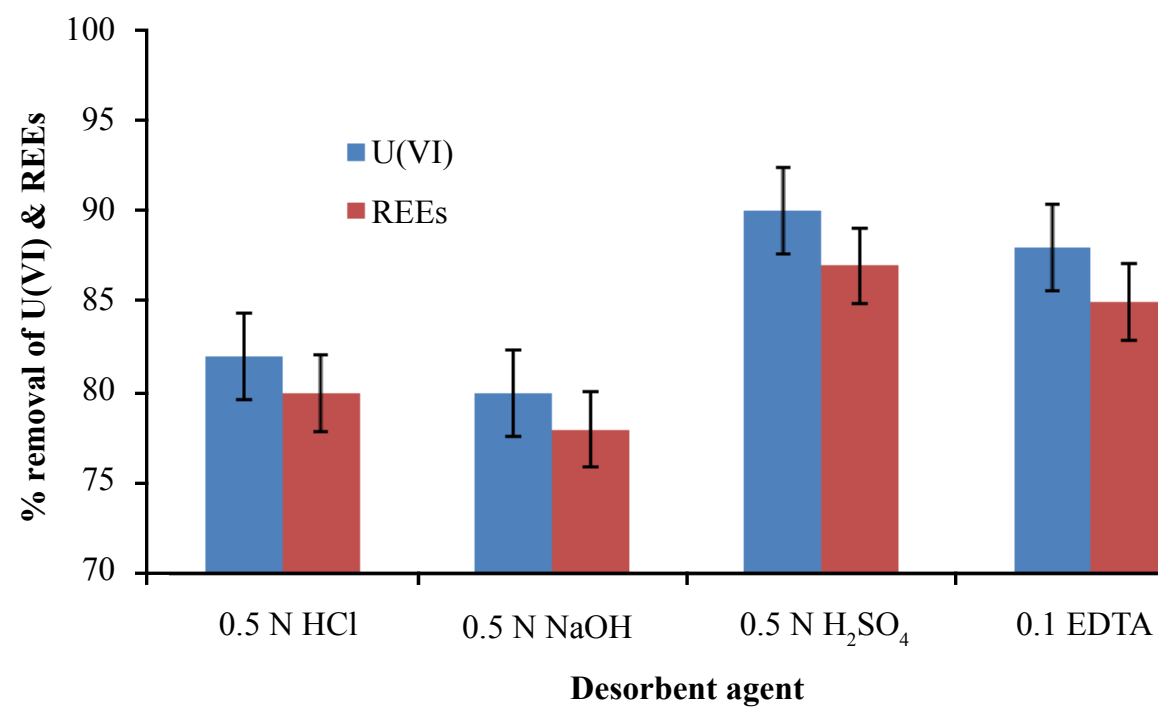

Figure 15: Desorption of $\mathrm{U}(\mathrm{VI})$ \& REEs ions with different desorbent agents. 


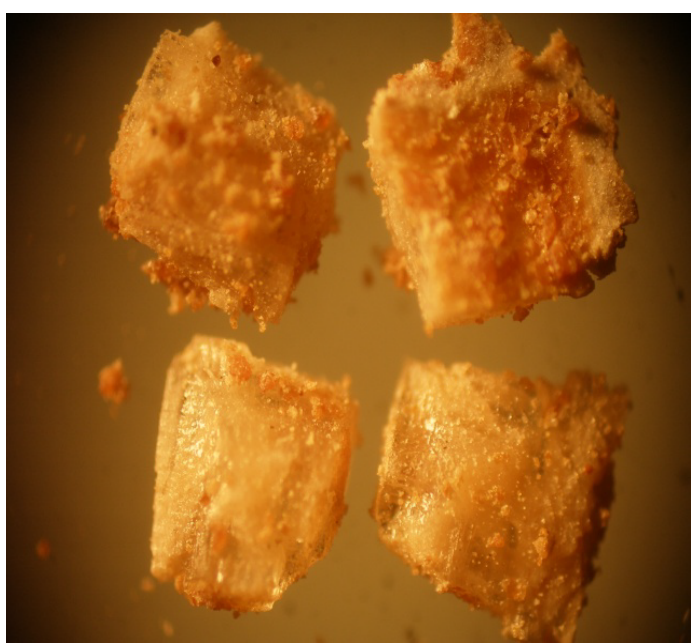

(A)

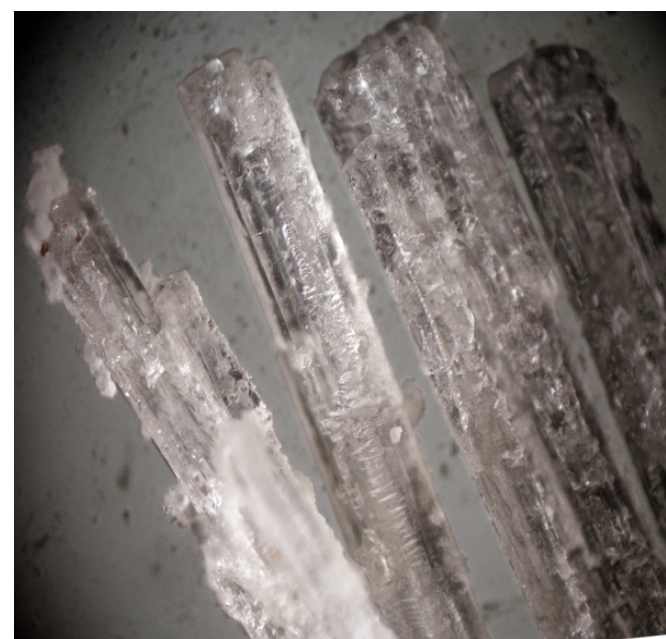

(B)

Figure 16: Stereo-photographs for the crystals of ammonium diuranate and rare earths oxalate precipitated from the desorbed liquor.

A) Aggregates of radiated crystals (needles form) of uranophane. $X=20$; B) Aggregates of colorless prismatic crystals form of rare earths oxalate. $X=20$.

desorbed $\mathrm{U}(\mathrm{VI})$ \& REEs ions from the biomass using $0.5 \mathrm{~N} \mathrm{HCl}$, $0.5 \mathrm{~N} \mathrm{NaOH} 0.5 \mathrm{~N} \mathrm{H}_{2} \mathrm{SO}_{4}$ and $0.1 \mathrm{~N}$ EDTA for three washing cycles. It was found that $0.5 \mathrm{~N} \mathrm{H}_{2} \mathrm{SO}_{4}$ desorbent agent eluted about 90 \& $88 \%$ of the biosorbed U(VI) \& REEs ions by $E$. coli biomass after three cycles, respectively. Higher acid concentrations could be produced higher concentration of protons which swept the metal ions away from the biosorbent. As expected, a slightly lower in weight loss could be achieved by $0.5 \mathrm{~N} \mathrm{H}_{2} \mathrm{SO}_{4}$ compared to other desorbent agents so, it safe to be used for desorption purpose without increasing the biomass weight loss [8].

\section{Characterization of the obtained crystals of $\mathrm{U}(\mathrm{VI})$ \& REEs using BSM}

Some crystals from ammonium diuranate and rare earths oxalate precipitated from $0.5 \mathrm{~N} \mathrm{H}_{2} \mathrm{SO}_{4}$ desorbed liquor were stereo-photographed using Binocular Stereo-Microscope (BSM). Figure 16 illustrates stereo-photographs for the crystals of ammonium diuranate and rare earths oxalate precipitated from the desorbed liquor which may be: A) Aggregates of radiated crystals (needles form) of uranophane. $X=20$ and B) Aggregates of colorless prismatic crystals form of rare earths oxalate. $X=20$.

\section{Conclusion}

In this study, the optimum leaching conditions of laterite ore were: $2 \mathrm{M}$ acid with a Solid/Liquid ratio of $1 / 20$ at $90^{\circ} \mathrm{C}$ for $4 \mathrm{~h}$ and using an ore size of -60 mesh. Under these conditions, the maximum leaching efficiency was $85 \%$ for REEs and 218 ppm for uranium. The biosorption properties of $E$. coli biomass were studied intact time, biosorbent do for U(VI) \& REEs ions recovery from chloride leach liquor of laterite ore. The results obtained show cosage, temperature, agitation rate and biosorbent pretreatment highly affect the uptake. Uranium and REEs ions removal from chloride leach liquor of laterite ore by $E$. coli biomass was found $75 \%$ and $65 \%$, respectively.
The tested sample can provide ready access and rich surface area for uranium \& REEs ions onto the binding sites by FTIR \& SEM analyses. In conclusion, E. coli was considered promising biosorbent agent used for the removal of $\mathrm{U}(\mathrm{VI})$ \& REEs ions from chloride leach liquor of laterite ore.

\section{References}

1. Abdel Moneim A (2005) Uranium extraction from abu zeneima sedimentary ore material. PhD Thesis Fac. Sc, El- Mansoura Univ, Egypt.

2. El Hazek MN, Ahmed FY, El Kasaby, et al. (2008) Sulfuric acid leaching of polymetallic abu zeneima laterite-shale. Hydrometallurgy 90: 34-39.

3. Valix M, Usai F, Malik R (2001) Fungal bio-leaching of low grade laterite ores. Min Eng 14: 197-203.

4. Diniz V, Volesky B (2005) Biosorption of La, Eu and Yb using sargassum biomass. Water Res 39: 239-247.

5. Wu DB, Niu CJ, Li DQ, et al. (2004) Solvent extraction of scandium (III), yttrium (III), lanthanum (III) and gadolinium (III) using Cyanex 302 in heptane from hydrochloric acid solutions. J Alloys Compd 374: 442-446.

6. Vijayaraghavana A, Mahadevanb UM Joshi, Balasubramanianb R (2009) An examination of the uptake of lanthanum from aqueous solution by crab shell particles. Chem Eng J 152: 116-121.

7. Nilanjana D, Vimala R, Karthika $P$ (2008) Biosorption of heavy metals- An overview. Ind J of Biotechno 7: 159-169.

8. Hufton J (2016) The role of the bacterial cell surface and extracellular macromolecules in $\mathrm{U}(\mathrm{VI})$ biosorption and biomineralisation. PhD thesis, Faculty of Social Science, University of Sheffield.

9. Tong K (2017) Preparation and biosorption evaluation of Bacillus subtilis/alginate-chitosan microcapsule. Nanotech Sci and Applicat 10: 35-43.

10. American Public Health Association (APHA) (2005) American water works association (AWWA) \& water environmental 
federation (WEF): Standard methods for examination of water and wastewater. $\left(21^{\text {st }}\right.$ edn),

11. Marczenko Z (1976) Spectrophotometric determination of elements. John Wiley and Sons, New York.

12. Soe NN, Shwe LT, Lwin KT (2008) Study on extraction of lanthanum oxide from monazite concentrate. Wor Aca of Sci. Eng. \& Technol 46: 142-145.

13. Steel RGd, Torrie JH, Dickery D (1997) Principales and procedures of statistics. A Biomaterial Approch. ( $3^{\text {rd }}$ edn), McGraw Hill Book co. Inc., New York, USA.

14. Hussien SS, Desouky OA (2014) Biosorption studies on yttrium using low cost pretreated biomass of Pleurotus ostreatus. (4 ${ }^{\text {th }}$ edn), Int. Con. Rad. Res. Appl. Sci., Taba, Egypt, 139: 150.

15. Chakravarty P, Sarma NS, Sarm HP (2010) Removal of lead (II) from aqueous solution Using heartwood of Areca catechu powder. Desalination 256: 16-21.

16. Yang SK, Tan N, Yan XM, et al. (2013) Thorium(IV) removal from aqueous medium by citric acid treated mangrove endophytic fungus Fusarium sp. \#ZZF51. Mar Pollut Bull 74: 213-219.

17. Carol D, Kingsley SJ, Vincent S (2012) Hexavalent chromium biosorption from aqueous solutions by Pleurotus ostreatus spent biomass. International Journal of Engaineering Science and Technology (IJEST) 4: 7-22.

18. Ekebafe LO, Ekebafe MO, ErhUaga GO, et al. (2012) Effect of reaction conditions on the Uptake of selected heavy metals from aqueous media Using composite from renewable materials. American Journal of Polymer Science 2: 67-72.
19. Ahalya N, Kanamadi RD, Ramachandra TV (2003) Biosorption of heavy metals. Research Journal of Chemistry and Environment 7: 71-78.

20. Shuxia XU, Shimin ZHANG, Ke CHEN, et al. (2011) Biosorption of $\mathrm{La}^{3+}$ and $\mathrm{Ce}^{3+}$ by Agrobacterium sp. HN1. J Rare Earths 29: 265-270.

21. Jin, Yu, Xin Wang, Tingting Zang, et al. (2016) Biosorption of Lead(II) by Arthrobacter sp. 25: Process Optimization and Mechanism J Microbiol Biotechnol 26: 1428-1438.

22. Merroun ML, Geipel G, Nicolai R, et al. (2003) Complexation of $\mathrm{U}(\mathrm{VI})$ by the three eco-types of Acidithiobacillus ferrooxidans studied using time-resolved laser-induced fluorescence spectroscopy and infrared spectroscopy. Biometals 16: 331-339.

23. Li H, T Liu, Z Li, et al. (2008) Low-cost supports used to immobilize fungi and reliable technique for removal hexavalent chromium in wastewater. Biores Technol 99: 2234-2241.

24. Yee N, LG Benning, VR Phoenix, et al. (2004) Characterization of metalcyanobacteria sorption reactions: A combined macroscopic and infrared spectroscopic investigation. Environ Sci Technol 38: 775-782.

25. Pavasant $P$, Apiratikul $R$, SungkhUm $V$, et al. (2006) Biosorption of $\mathrm{Cu}^{2+}, \mathrm{Cd}^{2+}, \mathrm{Pb}^{2+}$, and $\mathrm{Zn}^{2+}$ using dried marine green macroalga Caulerpa lentillifera. Bioresour Technol 97: 2321-2329.

26. Huang F, Dang Z, Guo CL, et al. (2013) Biosorption of Cd(II) by live and dead cells of Bacillus cereus RC-1 isolated from cadmiumcontaminated soil. Colloids Surf B Biointerfaces 107: 11-18.

27. Kazy SK, Das SK, Sar P (2006) Lanthanum biosorption by a Pseudomonas sp.: equilibrium studies and chemical characterization. J Ind Microbiol Biotechnol 33: 773-783.

DOI: $10.36959 / 742 / 215$

Copyright: (C) 2019 Hussien SS, et al. This is an open-access article distributed under the terms of the Creative Commons Attribution License, which permits unrestricted use, distribution, and reproduction in any medium, provided the original author and source are credited. 